(Not to be reproduced without permission of authors)

November 2011

\title{
DEGRADED WORK, DECLINING COMMUNITY, RISING INEQUALITY, AND THE TRANSFORMATION OF THE PROTESTANT ETHIC IN AMERICA: 1870-1930
}

\author{
Jon D. Wisman and Matthew Davis ${ }^{1}$
}

"Economic acquisition is no longer subordinated to man as the means for the satisfaction of his material needs.... The earning of money within the modern economic order is... the result and expression of virtue and proficiency in a calling; and this virtue and proficiency are, as it is... not difficult to see, the real Alpha and Omega of Franklin's ethic" (Weber 1904: 53-4).

"In modern civilized communities the lines of demarcation between social classes have grown vague and transient, and wherever this happens the norm of reputability imposed by the upper class extends its coercive influence with but slight hindrance down through the social structure to the lowest strata. The result is that the members of each stratum accept as their ideal of decency the scheme of life in vogue in the next higher stratum, and bend their energies to live up to that ideal. On pain of forfeiting their good name and their self-respect in case of failure, they must conform to the accepted code, at least in appearance..... No class of society, not even the most abjectly poor, foregoes all customary conspicuous consumption" (Veblen 1899: 84, $85)$.

"Apart from its biological functions, the family served as a key institution of social life, production, and consumption. Of these three, capitalism leaves only the last, and that in attenuated form, since even as a consuming unit the family tends to break up into component parts that carry on consumption separately" (Braverman 1974: 277).

ABSTRACT: The Protestant ethic has been depicted as declining in America between 1870 and 1930, due to new affordable consumer durables and less rewarding industrial work. This article re-examines this period and finds that the Protestant ethic did not so much decline as become transformed. The work ethic component remained in force, while abstemious consumer behavior weakened. This transformation is traced to three

\footnotetext{
${ }^{1}$ The authors are Professor of Economics and Ph.D. Candidate in Economics, respectively, at American University, Washington, D.C. Helpful comments from John Willoughby are gratefully acknowledged.
} 
dynamic social forces of the period: Degradation in the quality of work, the decline of community, and a dramatic increase in inequality. Industrialization degraded work as craft industries and independent farming waned, thereby making it more difficult for others to know the quality and intensity of ones work. However, the amount one consumed could serve as a proxy for hard work. Consequently, social respect and social standing came increasingly to be sought through consumption. Industrialization-driven urbanization also made it more difficult to find social certification not only in work but also in community. Growing inequality over this period prompted individuals to save less and become more indebted so as to be able to consume at the higher level necessary for maintaining their relative social standing. The durable goods revolution, although technologically driven, was also fueled by the degradation of labor, the decline of community, and rising inequality.

KEYWORDS: social mobility; deskilling; loss of community; conspicuous consumption; social status

CLASSIFICATION CODES: N31, N32, Z1, B52.

\section{INTRODUCTION}

Historians are in general agreement that beginning with European colonialization, the Protestant Ethic ${ }^{2}$ played a critical role in the economic and cultural experience of the United States. There is also broad agreement that the industrialization of America between 1870 and 1930 transformed this ethic, to such an extent that many cultural historians have interpreted it as declining. ${ }^{3}$

Some have linked this transformation/decline to the emergence of consumerism

and a weakening of ascetic abstemious behavior (e.g., Olney 1991; Bell 1976, 1996).

\footnotetext{
${ }^{2}$ Debate surrounding practically every aspect of the Protestant Ethic has been vibrant ever since the publication of Weber's seminal work in 1904. On the current status of the Protestant work ethic (PWE), Furnham notes that "although the validity of the historical, economic, sociological and theological hypothesis remains in doubt, and hotly debated few have denied the validity and accuracy of Weber's specifications of behaviour patterns, goals and values dictated by the PWE, namely asceticism, hard work, postponement of gratification, thrift, frugality, etc... [Further], More than a decade of intensive work on the PWE belief construct has confirmed its place as an important individual difference variable related to human motivation" (1984: 88; 100). Daniel Bell declares that Weber's book, The Protestant Ethic and the Spirit of Capitalism...is probably the most important sociological work of the twentieth century (1996: 35).

${ }^{3}$ Virtually all commentators who see a decline in the Protestant Ethic see it occurring either during the period under discussion in this article or in the middle decades of the second half of the $20^{\text {th }}$ century (For a review of those who stress the latter period, see Furnham 1990: 203-206).
} 
Others have pointed to the fact that industrialization altered the nature and quality of work. Whyte, for instance, claimed that in the larger institutions that came with industrialization, it became clear that reward and recognition were no longer linked to performance (1956: 16-17). Similarly, Eisenberger (1989) viewed the Protestant Ethic in "terminal decline" by the time of the Great Depression due to the inability to take pride in ones work resulting from strenuous assembly-line positions producing low quality goods. This lack of pride in work caused it to be seen as a negative aspect of life which resulted in both increased value being placed on leisure time and a declining emphasis on the moral value of work in religious life, a view that quickly spread from factory workers to white-collar workers and eventually to society at large. The increased value placed on leisure drove the subsequent increase in demand for consumer products.

Rodgers argues that by the 1920 s, the Protestant Ethic was "gutted" due to a combination of the above factors: that the opportunities for advancement based on hard work ceased to exist, that the opportunity for creative pride in ones work disappeared, and furthermore, that the new consumer goods created an increased desire for leisure, with the ultimate achievement being freedom from labor (1978: 28-29). Lutz, referencing the 1927 work of Langdon Mitchell on the subject of American malaise, notes that "Historians have been nearly unanimous in interpreting statements like Langdon Mitchell's about a lack of work satisfaction as further evidence of what they see as the disappearance of the work ethic by the 1920s" (1996: 260). Zuboff argues that as work lost its intrinsic meaning, the old work ethic disappeared and the new mass production systems demanded "a new work ethic that would substitute extrinsic rewards for intrinsic satisfaction" (1983: 163). 
Applebaum, in contrast, found that a "work ethic" persisted, although it was transformed from an "artisanal" work ethic into an "industrial" one - where pride in the actual work done became less important, but pride in working and working hard remained. In this reformulated work ethic, quality of work lost out as society adjusted to a life controlled by the factory clock (1998: 65, 92-96). Even at the time, there was concern that the work ethic was fading: the Saturday Evening Post, in an article titled "Sweat or Die," declared the United States to be "long on trouble and short on sweat," and that "work is the cure" (Wiley 1920:31).

Although the above arguments have identified important dynamics in the forces transforming the Protestant Ethic, together they do not provide a coherent account or capture the full story. They especially do not ground this transformation in the social dynamics underlying the Protestant Ethic, the fact that prior to this period, its social function was due to the fact that hard work and abstemious behavior were highly approved, thereby providing individuals and families with social and self-respect.

This article provides a more comprehensive explanation of what happened to the Protestant ethic between 1870 and 1930 by re-examining it in terms of its social function of providing a behavioral code for acquiring and maintaining social respectability and status. In doing so, it draws upon the general perspective on human behavior developed in the works of two very different economists, Adam Smith's Theory of Moral Sentiments and Thorstein Veblen's Theory of the Leisure Class. ${ }^{4}$ In spite of the differences in these

\footnotetext{
${ }^{4}$ Although Smith is renowned as the father of modern economics, his earliest work, and to his mind his best (Ray 1895: 436), is not appreciated or even well known within the profession. Further, the approbation theories of human behavior formulated by Smith and Veblen play no role in mainstream economics. The principal reason is that these approbation theories are constructed on the strong assumption that peoples' preference functions are highly interdependent. Neoclassical economics views them as independent.
} 
theories, both share the view of humans as strongly motivated by the need for social approval. Both theories conclude that humans do not pursue such ends as wealth, fame, or glory for their own sakes. Instead, they do so because within modern societies attaining these ends gains the approbation of others, ${ }^{5}$ which is a requirement for many social rewards. Social approbation is also a requirement for self-respect. When viewed from this behavioral perspective, the character of the transformation of the Protestant Ethic between 1870 and 1930 becomes clearer. The two principle components of the Protestant ethic -- hard work and ascetic abstemious behavior - were challenged by three interrelated consequences of industrialization: the degradation of work, the decline of community, and rising inequality.

The quality of work was degraded and increasingly unavailable for observation as craft industries and independent farming declined and ever-more workers entered into industrial occupations where the worker's skill and diligence were not clearly visible. A critical source for social and self-respect was thereby weakened. As this industrialization led to greater urbanization, communities within which the actual performance of work might be observed also declined, making it more difficult for others to know how hard or well someone worked. Thus, combined with the degraded quality of work, rising industrial urbanization made it more difficult to find social certification in community. Consequently, individuals increasingly began to seek social certification through consumption, which could serve as an observable consequence, or gauge, of hard work,

\footnotetext{
${ }^{5}$ It should be noted, however, that pursuit of these ends would have been punished as opposed to approved in hunter and gatherer societies. Therefore, because humans spent about 95 percent of their history in these earlier societies, it would be a mistake to assume that the specific pursuit of wealth, fame, and glory are what human nature dictates.
} 
since presumably, harder work permits greater consumption. ${ }^{6}$ It should also be noted that compared to work, consumption is a more efficient way of showing success to large numbers of people; while hard work is visible only to those who can see or know of ones workplace, much consumption is visible to a great number of people with whom there is contact.

Growing inequality between 1870 and 1930 -- especially after World War One -put pressure on households to consume more to maintain their relative social status or social respectability. As noted above, such consumption served as a proxy for how hard one worked. Although the emergence of consumerism was in part due to the technologically-driven durable goods revolution, this revolution was itself fueled by the rising demand for such goods as a consequence of the degradation of work, declining community, and rising inequality.

Within this context, the depiction of a consumer society as representative of a decline in the Protestant ethic between 1870 and 1930 is only partially correct. It is true that the ascetic abstemious behavior of Protestantism weakened during this period. So too did pride in the quality of work. But hard work did not become less important. Instead, consumption evolved as the predominant viable means by which the virtue of hard work could be socially communicated. Consumption became a proxy for hard work. The Protestant ethic was transformed from a behavioral code that favored both hard work and asceticism in consumption to one that continued to privilege hard work, but needed

\footnotetext{
${ }^{6}$ Davis notes research that concludes that "Wealth in America is often a symbol of occupational achievement which is in many cases the ultimate criterion of status. But our occupational system includes so many complex skills that popular recognition of them is impossible. Hence income is taken as a least common factor, a rough index of achievement. It is an easy step from there to the emphasis on display and conspicuous consumption which Veblen noted so clearly" (1944: 284).
} 
visible consumption to socially communicate this, and thus, ascetic behavior in consumption was sacrificed in order to maintain the high value placed on work.

\section{WORK, SOCIAL RESPECTABILITY, AND SELF-RESPECT}

The bourgeoisie in Europe owed its status not to birth, as was the case of the aristocracy, but to work. It is not surprising, then, that the new expressions of Christianity that arose in support of the institutions and behavior of this new class would especially honor work. ${ }^{7}$ The pursuit of material success had been negatively viewed by Catholicism. ${ }^{8}$ Consequently, the hard work that enabled the bourgeois to improve their status needed to be ideologically expressed in religious terms that saw it as a "calling," an utter devotion to ones vocational duty, as opposed to a means of getting rich. Work was a worldly way to serve God, and thus it had a divine dignity. ${ }^{9}$ Ascetic consumption behavior not only augmented the material success resulting from hard work, it also made clear that this wealth was not for pleasure or sensual ends, thereby making its accumulation more seemingly consonant with traditional Christian values that disapproved of wealth seeking.

Thus, the earliest Protestants were hostile to secular acquisitiveness or anything else that might draw attention away from God. The idea of a "calling" provided a bridge to worldly affairs and thus the centrality of work. It was also a duty to God not to take

\footnotetext{
${ }^{7}$ Further evidence that the Protestant work ethic reflected the rise of a commercial bourgeoisie is provided by the fact that a strong Calvin-like work ethic also developed in Japan among merchants as their power and status rose in the seventeenth century (Landes 1998: 363).

${ }^{8}$ The principal virtues emphasized by Catholicism were "good works," understood as charity and religious observances.

${ }^{9}$ Weber wrote of the development within the Protestant faith of the concept of a "calling (in the sense of a life-task, a definite field in which to work)" (1904: Ch. 3).
} 
too great enjoyment in this world, and thus excessive consumption was to be shunned.

Nevertheless, accumulating wealth was evidence of hard work, and came to be viewed, especially among Calvinists, as a sign of eternal salvation. ${ }^{10}$ However, this wealth was valued not as wealth per se, but rather as evidence of merit, and ultimately it belonged to God, not the individual. As Buchholz notes, "The more possessions one had, the greater was the obligation to be an obedient steward and hold these possessions undiminished for the glory of God by increasing them through relentless effort" (1998: 873). Individuals should not consume this wealth, but be caretakers of what is God's bounty. This could mean, as Andrew Carnegie interpreted it in The Gospel of Wealth (2006), that it was to be used for the betterment of society.

The Protestant ethic evolved into a code of conduct for individuals, serving to guide their pursuit of social approbation, social respectability, and social status. Its general thrust was that status is to be derived from hard work, not the taking of pleasure in consumption. ${ }^{11}$ This ethic is grounded in the fact that social status is critically important to people and thus strongly affects their behavior, where social status is meant in the broad sense whereby an individual is motivated, as Karl Polanyi put it "to safeguard his social standing, his social claims, his social assets. He values material goods only in so far as they serve this end" (1944: 46). The human preoccupation with

\footnotetext{
${ }^{10}$ A revised appreciation of wealth came to characterize Protestantism in the U.S. by the early twentieth century. Note the following passage in Russell Conwell's Acres of Diamonds, a book published in the U.S. in 1915 that would go on to sell 10 million copies:

"I say that you ought to get rich, and it is your duty to get rich....Some men say, 'Don't you sympathize with the poor people?' Of course I do, or else I would not have been lecturing all these years. But the number of poor who are to be sympathized with is very small. To sympathize with a man whom God has punished for his sins, thus to help him when God would still continue his punishment, is to do wrong, no doubt about it" (1915: 17; 21).

${ }^{11}$ As Daniel Bell put it, "The Protestant ethic as a way of life...was one of piety, frugality, discipline, prudence, the strenuous devotion to work, and delayed gratification" (1996: 35).
} 
status or relative social position is understandable from an evolutionary perspective.

Those with higher status, whatever its source, would possess disproportionate access to resources and members of the opposite sex, thus permitting more and better-cared-for progeny. A proclivity for seeking status would thus be naturally selected. Or, as Frank has put it, "falling behind ones local rivals can be lethal" (2005: 183).

How people are judged by others constitutes the foundation for self-esteem, which John Rawls claimed to be "perhaps the most important primary good," such that without it nothing else has much value (1971: 440). ${ }^{12}$ As Sayer, drawing on the work of Gilligan (2000) and Sedgwick and Frank (1995) notes, "The vulnerability of individuals consists in their dependence on others and not only for material support but for ongoing recognition, respect, approval and trust. While this may be adequately provided by small numbers of others, its absence can cause severe distress, shame and self-contempt indeed, sometimes individuals may value respect more than their own lives" (2005: 54). Thus, “...recognition is not a luxury that ranks lower than the satisfaction of material needs, but is essential for well-being" (Sayer 2005: 54).

Even Adam Smith recognized that certain positions were viewed by society as "honorable," and that compensation was necessary to induce a worker to take a job lacking in honor: "Honour makes a great part of the reward of all honourable professions. In point of pecuniary gain, all things considered, they are generally under-recompensed, as I shall endeavour to shew by and by. Disgrace has the contrary effect" (1776: 117).

THE PROTESTANT ETHIC AND U.S. ECONOMIC DEVELOPMENT

\footnotetext{
${ }^{12}$ This point was forcefully made by Veblen: "The usual basis of self-respect is the respect accorded by one's neighbors. Only individuals with an aberrant temperament can in the long run retain their self-esteem in the face of the disesteem of their fellows" (1899: 39).
} 
For the initial European settlers of the New World, hard work was not so much a choice as a necessity. For the vast majority, life was mainly one of self-sufficiency and subsistence, and the relationship between hard work and personal success was clearly evident. The Protestant sects that accompanied these colonialists legitimated these values of hard work and limited consumption. With consumption constrained, ${ }^{13}$ more income could be saved and invested, thereby providing an impetus for economic growth.

The Protestant work ethic promoted community values. Weber noted that “...the usefulness of a calling, and thus its favour in the sight of God, is measured primarily in moral terms, and thus in terms of the importance of the goods produced in it for the community" (1904: 162). The special force of the Protestant Ethic that caught Weber's attention may have been due to a number of factors, most notably the character of those who immigrated to America and perhaps especially to the strong belief in vertical social mobility. Weber also wrote of the central importance of the concept of a calling in America. ${ }^{14}$ The vital importance of religion in American life had been earlier noted by de Tocqueville: "There is no country in the world where the Christian religion retains a greater influence than in America" (1945, vol. 1: 314). ${ }^{15}$ The Protestant Ethic served to nurture the rise of economic growth as a social value, where economic success (measured by growth) served to indicate whether a society is on a morally correct path (Powers

\footnotetext{
${ }^{13}$ In the early twentieth century, Graeber claimed that "Americans have, since colonial days, been the population least sympathetic to debtors. (Back then, the ears of an insolvent debtor would often be nailed to a post.) The notion of morality as a matter of paying one's debts runs deeper in the United States than in almost any other country, which is odd, since America was settled largely by absconding debtors" (Graeber 2011).

${ }^{14}$ Interestingly, he noted that even the uniform clothing styles promoted by the Puritans laid the groundwork for future industrial standardization ([1904] 1958: 169).

${ }^{15}$ He also noted that "Various forms of religious madness are quite common in the United States" (1945: vol. 2: 623).
} 
1976: 31).

Making the work ethic especially forceful in the U.S. was the fact that since colonial times, due to weak class demarcations, there has been a relatively strong belief that vertical mobility was readily possible. ${ }^{16}$ Where the potential for vertical mobility is relatively high, class distinctions are blurred. ${ }^{17}$ Although individuals in the U.S. may have had a general sense of where they fell in terms of their society's distribution of income or wealth, they had little sense of belonging to a class. Because of a strong belief in the potential for vertical mobility, Americans generally felt responsible for their own social status. If they were willing to put forth sufficient effort, they felt that they could improve their status. Through adequate dedication and effort, anyone could move up, even to the very highest levels of social status. It was the individual's responsibility and depended upon the individual's willingness to study and work hard. ${ }^{18}$ Ones social status was not given, but earned. ${ }^{19}$

\footnotetext{
${ }^{16}$ Alexis de Tocqueville and Karl Marx both noted an exceptionally high degree of vertical mobility in the U.S. and termed it "American exceptionalism." The extreme extent to which de Tocqueville believed this to be true is captured in the following passage from Democracy in America: "To tell the truth, though there are rich men, the class of rich men does not exist...the rich are constantly becoming poor" $(1945$, vol. 2 : 160).

${ }^{17}$ Vertical mobility became most fully developed first in those capitalist countries that were essentially composed of immigrants who had left behind worlds of more rigid status barriers. Thus not surprisingly, considerable vertical mobility was found in countries populated by immigrants such as the U.S., Canada, Australia, and Israel (Tyree et. al. 1979: 415).

${ }^{18}$ The reverse also might be expected to hold. In a nation in which there is a relatively strong belief in the possibility of vertical mobility and in which income distribution is highly unequal, individuals would not only readily take credit for their economic successes, but also readily view the less fortunate as responsible for their economic failures. Therefore, welfare measures would be undeserved, if not corrupting. Criminal conduct would merit stiff punishment.

${ }^{19}$ By contrast, in traditional societies in which status was ascribed by birth, high-status individuals felt their status was their right. Indeed, they generally understood themselves to be in fact superior, whereas those below felt themselves to be in fact inferior. Note the extreme case of India's "untouchables," who, until fairly recently in their history, generally believed that their grim existence at the bottom of the social structure was just, due to poor karma in an earlier incarnation.
} 
It should be noted, however, that in spite of the strength of the Protestant ethic in America, the attitude toward work was not without ambiguity. This was made clear by Veblen's studies of the various ways in which people struggled to exhibit leisure status, that is, to be viewed as above work. He noted, for instance, that "wealth acquired passively by transmission from ancestors or other antecedents presently becomes even more honorific than wealth acquired by the possessor's own effort." And, "The leisure class stands at the head of the social structure in point of reputability; and its manner of life and its standards of worth therefore afford the norm of reputability for the community" (1899: 29; 84). The reason for this, he claimed, is that "During the predatory culture labour comes to be associated in men's habits of thought with weakness and subjection to a master. It is therefore a mark of inferiority, and therefore comes to be accounted unworthy of man in his best estate. By virtue of this tradition labour is felt to be debasing, and this tradition has never died out" $(1899: 36) .^{20}$

\section{INDUSTRIALIZATION AND THE DEGRADATION OF WORK}

In the wake of the Civil War, the U.S. economy launched into a process of rapid industrialization, ${ }^{21}$ transforming practically all aspects of American society. However, three aspects stand out that have critical relevance for the Protestant Ethic: the nature of work, the decline of community, and greater inequality. The result of industrialization

\footnotetext{
${ }^{20}$ Veblen (1899) goes on to argue, however, that as the population becomes more mobile, communities become less close-knit such that people are less well informed of the leisure activities in which other people engage, and so the display of wealth through consumption of goods becomes more important than the display of leisure. It is curious that whereas Veblen viewed much consumption as a resource wasteful pursuit of higher status, he saw attraction to work as driven by an instinct - the instinct of workmanship, and not as driven by a Protestant Ethic.

${ }^{21}$ The pace of U.S. industrialization was such that whereas in 1860, the U.S. "ranked behind England, France, and Germany in the value of its manufactured product, [In] 1894...its manufactured product nearly equaled in value that of Great Britain, France, and Germany together" (Gutman 1973: 555).
} 
was that it became progressively more difficult for people to achieve their social identity and status from work and community, prompting them to seek it ever more in consumption. Growing inequality meant that household had to struggle ever harder to maintain their relative status. This section will address the manner in which industrialization changed the fundamental character of work. The following two sections will detail sequentially the accompanying changes in the character of community and the rise of inequality.

Industrialization entailed a dramatic decline in the percentage of workers who essentially controlled their workplaces directly, whether as independent farmers, craftsmen, or small shop owners, and a concomitant rise in those who worked as wageworkers with little if any control over the work process. In 1870, over half of all adults were self-employed, either in agriculture, crafts, or small proprietorships as ownerworkers (Carter et al. 2006 2:110,120). And even those who became wage-workers retained substantial control over the workplace as late as the 1880 s. Production was relatively small scale and technology relatively uncomplicated. Indeed, it was not uncommon for the "boss" to simply purchase the equipment and allow the workers to determine how to produce a given amount of output and how to divide among themselves the payment received (Montgomery 1983: 110-111).

But the increasing maturity of industrialization radically changed the labor process. Over the period 1870-1930, farming ceased to be the livelihood of the majority of Americans, declining from over 50 percent of the work force at the end of the Civil War to slightly over 20 percent by 1930 (see Figure 1). During the latter part of the period, due to productivity gains, the actual number of farmers declined, even as the total 
population of the U.S. substantially expanded and the amount of land dedicated to agricultural uses more than doubled (Carter et al. 2006, 4:50). This occurred while the average acreage of farms remained relatively constant, and was thus caused by an increase in the number of farms, but not farm size (Carter et al. 2006, 4:43). The ability to expand cultivated acreage so dramatically while using fewer workers per acre was largely due to labor-saving technology such as the tractor, the number of which increased from 1,000 in 1910 to 920,000 by 1930 (Carter et al. 2006, 4:80). Spending on manufactured inputs over this period grew by $282 \%$, while spending on hired labor increased by only 56\% (Carter et al. 2006, 4:197). Hatton and Williamson (1991), examining data on Michigan in the 1890s, find that farmers earned about half what unskilled urban workers earned (in nominal terms). After controlling for living costs, payment in kind, and personal characteristics of the laborer, ${ }^{22}$ they find that the wage gap shrinks to between 9 and 13 percent. However, this still represents a meaningful wage difference and is a comparison between farmers and unskilled builders or railroad workers - not higher-paid skilled urban factory workers (1991: 401-406) ${ }^{23}$. Many rural-to-urban migrants may have looked at factory work as their future, and seen robust wage increases. Aside from price concerns, a disconnect was growing between hard work and reward for the farmer. Anne Mayhew attributes the farm protest movement of the late $19^{\text {th }}$ century to this fact rather than to changes in actual economic conditions:

\footnotetext{
${ }^{22}$ While corrections for cost of living and payment in kind are important, correcting for family size and marital status of the worker do not aid in determining incentives for agents at the time. Hatton and Williamson (1991) find farm laborers (at their lower nominal wages) to be less likely to have a family, exactly as one would expect given self-selection into higher wage jobs for those with dependents. When these controls are removed, their data reveal a real wage gap of 13 to $16 \%$.

${ }^{23}$ Nominal, not real, wages may have been the drawing force insofar as many rural-to-urban migrants may may not have adequately anticipated the higher cost of urban living.
} 
“The farmer protested about his 'deteriorating' economic position because he was locked into a system where his success or failure now depended on prices - a system where, even if he was a 'good farmer' in pre-1860 terms, he might fail because he was a 'bad businessman' in late nineteenth-century terms.” (1972, 475).

The percentage of the non-agricultural labor force who were self-employed or engaged in unpaid family work also declined, from $23 \%$ in 1900 to $14 \%$ in 1930 (Carter et al. 2006, 2:120). Not only did the type of non-agricultural employment shift, but the work environment changed from predominantly small shops to increasingly large factory manufacturing. By 1929, $71 \%$ of manufacturing workers worked in factories of 100 or more workers, an increase from $61 \%$ in 1904, the earliest year for which data are available. Over the same time, the proportion of workers in establishments of 20 or fewer workers shrank from $13.6 \%$ to $9.8 \%$ (Granovetter 1984: 326).

FIGURE 1: PROPORTION OF LABOR FORCE ENGAGED IN AGRICULTURAL WORK

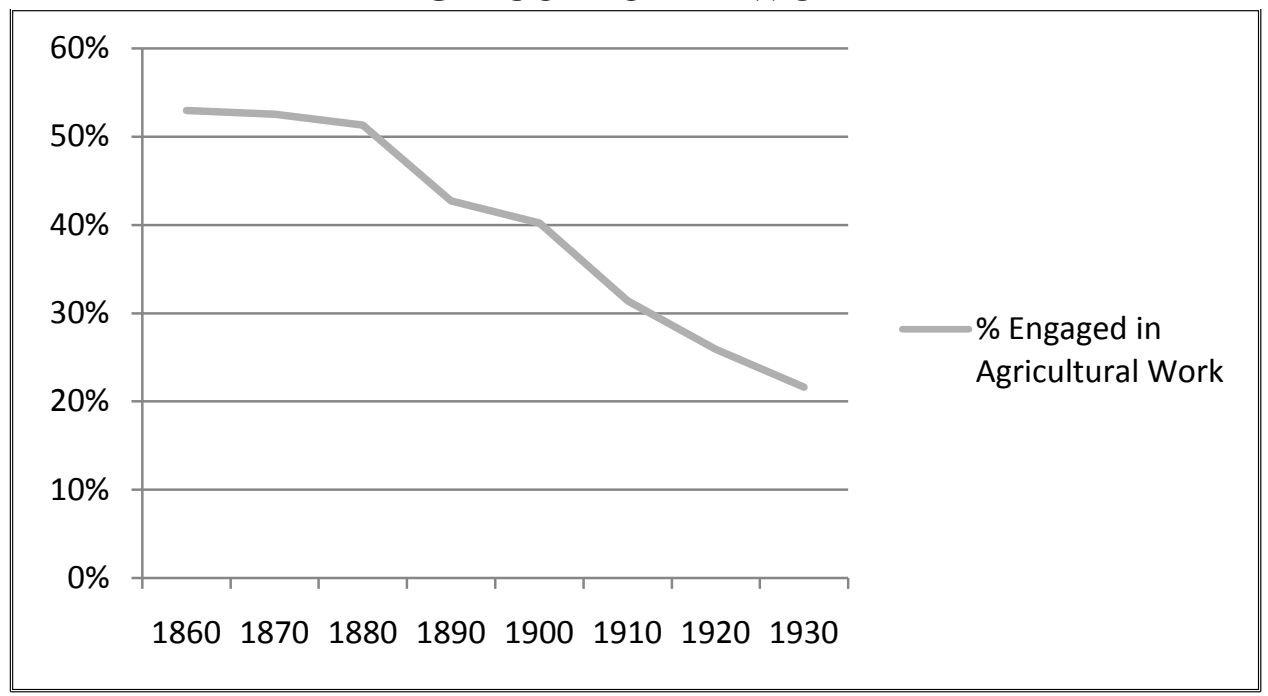

Source: Carter et al. 2006 2:110 


\section{FIGURE 2: PROPORTION OF LABOR FORCE SELF-EMPLOYED OR} ENGAGED IN UNPAID FAMILY WORK (INCLUDING AGRICULTURE)

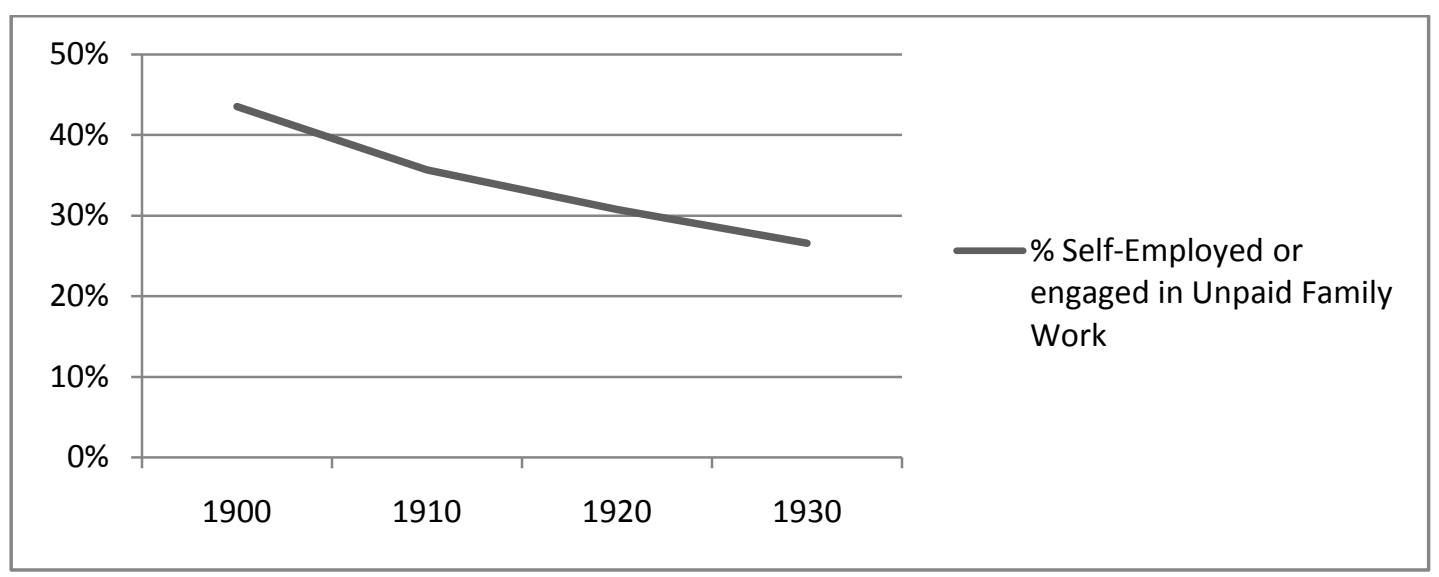

Source: Carter et al. 2006 2:110; 120

Workers were both pushed and pulled into industrial work. They were pushed by declining relative incomes due to falling agricultural prices brought on by productivity gains, or because their craft work was under-priced by factory output. They were pulled by higher relative standards of living as industrial workers. Both forces, of course, acted together in encouraging the migration to industrial work. Accompanying industrialization and urbanization were rapid declines in transportation costs, creating regional and even national markets for output. Thus whereas earlier workers' output was consumed by neighbors and other members of the community, increasingly workers' output was to be consumed by distant unknown consumers.

As more and more work was done in urban factories, some quite large, with the final product coming from the combined efforts of many individuals who performed small tasks, the diligence and hard work of individuals became less and less visible to others. Individuals progressively lost direct control not only over the quality of the product, also over how quickly they worked as the pace came to be determined by 
machinery. ${ }^{24}$ The eventually rise of the assembly line set the same pace for all. One mistake on the line by any individual would ruin any reputation of quality work for all workers.

The specialization of labor that came with industrialization brought with it massive increases in productivity. Perhaps an extreme example, when the first Ford assembly line opened, the time necessary to assemble one Model T dropped by 90 percent within three months (Braverman 1974: 147). The increased specialization that brought such gains also required taking complex, skilled tasks and subdividing them into specific movements and tasks requiring far less skill to perform. In fact, this was the stated goal of the new "scientific management," as exhibited in Taylor's Shop Management: "All possible brain work should be removed from the shop and centered in the planning or laying-out department" (Taylor 1911:98-99). Any creative participation by the worker was to be forbidden: "Under our system the workman is told minutely just what he is to do and how he is to do it; and any improvement which he makes upon the orders is fatal to success" (Taylor 1907; cited in Sohn-Rethel 1978, 152).

The first jobs to become mechanized were frequently the most skilled, where the high fixed costs of installing machinery were quickly recouped by the savings in labor costs from the wage difference between an unskilled machine operator versus a skilled artisan (Rodgers 1978: 66). As the jobs became uniformly deskilled, wages also equalized among the workers, who thereby lost their ability to showcase their hard work

\footnotetext{
${ }^{24}$ Accompanying this transformation was a decline in paternalism which, as Collins puts it, "operated through provision of nonwage goods and services, an ideology of beneficence, and the cultivation of deferential relations .... Through such means, paternalism had the effect of transforming power relations between company and its employees into moral obligations - a system of mutual responsibilities, duties, and ultimately, even rights" (2002: 157).
} 
relative to others by their higher salaries. Everyone worked at the same speed to produce the same number of units and everyone worked the same number of hours. The extent of deskilling was frequently extreme. Bright measured the overall skill level in manufacturing during this time of mechanization and surmised that, on average, the maximum skill required was that necessary to operate a hand controlled power tool. Increasing mechanization decreased the required skill contributions, particularly in key categories that were used to determine wages (1958: 45, 186-187).

Workers had a hard time adjusting to this new style of production, and turnover was very high. ${ }^{25}$ For instance, by the end of 1913 , to add 100 men to the labor force, the Ford company was required to hire 963 (Sward 1948:49). The wife of one of Henry Ford's assembly line workers wrote him in 1914 that "The chain system you have is a slave driver! My God! Mr. Ford. My husband has come home \& thrown himself down \& won't eat his supper - so done out! Can't it be remedied?" (Cited in Lacey 1986: 129).

As early as 1883, the Episcopal clergyman R. Heber Newton addressed the concern of a failing work ethic as false. Instead, he claimed that discontent among laborers was symptomatic of the new factory system. The typical factory employee, he wrote, "makes nothing. He sees no complete product of his skill growing into finished shape in his hands. What zest can there be in the toil of this bit of manhood?" (Recorded in Report of the Committee of the Senate. 1885: 549). Applebaum notes that as a result of the shift from a craft ethic to an industrial ethic during the early $20^{\text {th }}$ century, "Workers generally gave up hope of intrinsic satisfaction from factory work since the routinization and subdivision of work tasks rendered factory work monotonous and meaningless for

\footnotetext{
${ }^{25}$ Some workers left their jobs rather than suffer deskilling, long hours, and loss of control over the workplace (Rodgers 1978: 163-65).
} 
most workers" (1998:148). ${ }^{26}$ Concern over the mental degradation of work ${ }^{27}$ led to the rise of the "industrial betterment" movement around the turn of the century, with Jane Addams as a major spokesperson. Although many programs were instituted to boost morale, some with mild success, most labor advocates despaired of achieving more fulfilling work conditions, and pleaded instead for a reduction in working hours so as to enable workers to satisfy life needs outside the job (Rodgers 1978: 88-91). As Bauman has put it, "The true problem which the pioneers of modernization confronted was the need to force people, used to putting meaning into their work through setting its goals and controlling its course, to expend their skill and their work capacity in the implementation of tasks which were now set and controlled by others and hence meaningless for their performers" (2005: 7). ${ }^{28}$ To address this problem, by the 1920 s industrial relations came forth as a science of motivating workers. It was sold as welfare capitalism (Scase 1992).

For work to provide social certification of personal value and thus be a source for self-respect, how hard and well an individual worked had to be in some sense available for others to appreciate. As Sayer has put this, "While producing things (including providing services) and hence changing the social world around us can indeed help to create a sense of self-worth, this too depends on others who (a) recognize us as subjects capable of self-determination, and (b) are capable of judging and confirming the worth of

\footnotetext{
26 It should be noted that even much of the office work that arose with industrialization was viewed as degraded. In both Gilded Age America and Victorian Britain even the office worker was depicted as a pathetic creature. Note Bartleby the scrivener or Scrooge's assistant, Bob Cratchit.

27 The first recorded recognition of the mental impairment resulting from factory work was ironically Adam Smith, the great champion of the division of labor, which he claimed, over 700 pages into his classic, made workers "as stupid and ignorant as it is possible for a human creature to become" (1776: II: 782).

${ }^{28}$ Lane maintains that "There is evidence that exercise of discretion on the job, which is not so much a right as a requirement of complex tasks, has more substantial effect on self-esteem than any exercise of familiar political rights has ever had" (Lane 1991, 198).
} 
our labour" (2005: 56). But as industrialization proceeded, not only did work cease to be fulfilling, but how well and hard one worked became progressively less directly observable. What more readily caught attention was how much one could consume, which came to stand, more or less, as a signal for how hard one had worked. ${ }^{29}$ Thus, because Americans believed they were individually responsible for their own social standing, they felt strongly compelled to demonstrate status and hence class identity through consumption. ${ }^{30}$

An attempt to maintain or increase social standing through consumption is what Veblen meant by conspicuous consumption, a critical component of his theory of consumer behavior that is highly useful in understanding the turn toward consumption for social respectability and the influence of rising inequality upon consumption.

For Veblen, conspicuous consumption manifests itself in two dimensions. Consumption that permits "invidious comparison" is meant to demonstrate ones status to be above those below. "Pecuniary emulation," on the other hand, refers to the practice of imitating the consumption standards of those of higher status with the intent of appearing also to possess that status. Veblen claimed that "With the exception of the instinct of self-preservation, the propensity for emulation is probably the strongest and most alert and persistent of the economic motives proper" and "the propensity for emulation - for

\footnotetext{
${ }^{29}$ Scranton suggests that there were "three shifts: from ascetic dispositions toward goods to patterns of expressive possession, from a tendency to save to an appreciation of the duty to consume and from selfdefinition in terms of work or occupation to social placement defined largely through reference to commodities held by persons or families" (1994: 478).

${ }^{30}$ Riesman suggested yet another reason for the expansion of conspicuous consumption consequent to the changed character of work: "Conspicuous consumption is a form of escape from the regimentation and control of work" (Riesman 1953: 144).
} 
invidious comparison - is of ancient growth and is a pervading trait of human nature" (Veblen 1899: 110; 109).

Veblen's theory of consumer behavior is founded upon the fact that social status is critically important to people and thus strongly affects their behavior. ${ }^{31}$ The respect of others is critically important. Thus the consumer's "motive is a wish to conform to established usage, to avoid unfavourable notice and comment, to live up to the accepted canons of decency..." (1899: 115). Participation in conspicuous consumption is strongly socially compelled "though popular insistence on conformity to the accepted scale of expenditure as a matter of propriety, under pain of disesteem and ostracism." (1899: 111).

\section{INDUSTRIALIZATION AND THE DECLINE OF COMMUNITY}

In pre-industrial times, most Americans lived on rural farms, in villages, or in small towns, where hard work was directly linked to survival and easily visible to all in the community. Any farmer could tell if another was working hard by the size of the crops he brought in, given the easily observable information about size and quality of the fields cultivated. Likewise, the town blacksmith or tanner's work was generally consumed in the very town where it was produced, by the producer's neighbors, and thus served as a key determinant of the respect felt for that producer.

In small communities people generally know who is wealthier, who is more honorable, and whose past actions have been most beneficial to their collective ends. It

\footnotetext{
${ }^{31}$ Veblen essentially embraced what later social thinkers such as Bourdieu (1984) and Sayer (2005) refer to as a Pascalian view of human action, whereby rational deliberation is of lesser importance than socialization and habitualization. Thus conspicuous consumption for Veblen is not so much consciously pursued, but instead the engrained practice of struggling to maintain respectability:

"For the great body of the people in any modern community, the proximate ground of expenditure in excess of what is required for physical comfort is not a conscious effort to excel in the expensiveness of their visible consumption, so much as it is a desire to live up to the conventional standard of decency in the amount and grade of goods consumed" (1899: 102).
} 
follows that small and relatively isolated communities are freer of the ostentatious consumption practices that characterize the industrial era. Veblen notes that in such small-scale communities, societies' clothing fashions tend to be more stable and utilitarian (Veblen 1899: 175-76).

Over the time period of this study, a tremendous demographic shift occurred, as the urban share of population exploded from 26 percent in 1870 to 56 percent by 1930 (see Table 1). By 1930, 30 percent of the population lived in cities of more than 100,000 inhabitants - cities of such size that knowing everyone in the community was impossible, and inhabitants would not so frequently come upon or recognize the product of a fellow citizen's labor.TABLE 1: CHANGING RURAL URBAN POPULATION SHARES

\begin{tabular}{|cccccc|}
\hline Year & Total & Urban & Urban Share of & Rural & Rural Share of \\
& Population & Population & Population & Population & Population \\
\hline \hline 1870 & $\mathbf{3 8 , 5 5 8 , 3 7 1}$ & $\mathbf{9 , 9 0 2 , 3 6 1}$ & .257 & $\mathbf{2 8 , 6 5 6 , 0 1 0}$ & .743 \\
1880 & $\mathbf{5 0 , 1 8 9 , 2 0 9}$ & $\mathbf{1 4 , 1 2 9 , 7 3 5}$ & .282 & $\mathbf{3 6 , 0 5 9 , 4 7 4}$ & .718 \\
1890 & $\mathbf{6 2 , 9 7 9 , 7 6 6}$ & $\mathbf{2 2 , 1 0 6 , 2 6 5}$ & .351 & $\mathbf{4 0 , 8 7 3 , 5 0 1}$ & .649 \\
1900 & $\mathbf{7 5 , 9 9 4 , 5 7 5}$ & $\mathbf{3 0 , 2 1 4 , 8 3 2}$ & .398 & $\mathbf{4 5 , 7 7 9 , 7 4 3}$ & .602 \\
1910 & $\mathbf{9 1 , 9 7 2 , 2 6 6}$ & $\mathbf{4 2 , 0 6 4 , 0 0 1}$ & .457 & $\mathbf{4 9 , 9 0 8 , 2 6 5}$ & .543 \\
1920 & $\mathbf{1 0 5 , 7 1 0 , 6 2 0}$ & $\mathbf{5 4 , 2 5 3 , 2 8 2}$ & .513 & $\mathbf{5 1 , 4 5 7 , 3 3 8}$ & .487 \\
1930 & $\mathbf{1 2 2 , 7 7 5 , 0 4 6}$ & $\mathbf{6 9 , 1 6 0 , 5 9 9}$ & .563 & $\mathbf{5 3 , 6 1 4 , 4 4 7}$ & .437 \\
\hline
\end{tabular}

Source: Carter et al. 2006, 1:103-104

TABLE 2: GROWING CITY SIZE I

\begin{tabular}{|llll|}
\hline Year & Total & Number & Proportion \\
\hline \hline
\end{tabular}




\begin{tabular}{|lccc|}
\hline & Population & Living in Cities & Living in Cities \\
& & $>100 \mathrm{~K}$ & $>100 \mathrm{~K}$ \\
\hline \hline 1870 & $\mathbf{3 8 , 5 5 8 , 3 7 1}$ & $\mathbf{4 , 1 2 9 , 9 8 9}$ & .107 \\
1880 & $\mathbf{5 0 , 1 8 9 , 2 0 9}$ & $\mathbf{6 , 2 1 0 , 9 0 9}$ & .124 \\
1890 & $\mathbf{6 2 , 9 7 9 , 7 6 6}$ & $\mathbf{9 , 6 9 7 , 9 6 0}$ & .154 \\
1900 & $\mathbf{7 5 , 9 9 4 , 5 7 5}$ & $\mathbf{1 4 , 2 0 8 , 3 4 7}$ & .187 \\
1910 & $\mathbf{9 1 , 9 7 2 , 2 6 6}$ & $\mathbf{2 0 , 3 0 2 , 1 3 8}$ & .221 \\
1920 & $\mathbf{1 0 5 , 7 1 0 , 6 2 0}$ & $\mathbf{2 7 , 4 2 9 , 3 2 6}$ & .259 \\
1930 & $\mathbf{1 2 2 , 7 7 5 , 0 4 6}$ & $\mathbf{3 6 , 4 6 3 , 3 1 8}$ & .297 \\
\hline
\end{tabular}

Source: Carter et al. 2006 1:103-104

TABLE 3: GROWING CITY SIZE II

\begin{tabular}{|cccccc|}
\hline \multicolumn{7}{c|}{ Number of Cities/Towns With Given Population, by Year } \\
\hline \hline Year & $>1$ million & $>500,000$ & $>250,000$ & $>100,000$ & $>50,000$ \\
1870 & 0 & 2 & 7 & 14 & 25 \\
1880 & 1 & 4 & 8 & 20 & 35 \\
1890 & 3 & 4 & 11 & 28 & 58 \\
1900 & 3 & 6 & 15 & 38 & 78 \\
1910 & 3 & 8 & 19 & 50 & 110 \\
1920 & 3 & 12 & 25 & 68 & 145 \\
1930 & 5 & 13 & 37 & 94 & 192 \\
\hline
\end{tabular}

Source: Carter et al. 2006 1:102 


\section{FIGURE 3: PERCENTAGE OF AMERICANS LIVING IN URBAN AND RURAL AREAS, 1870-1930}

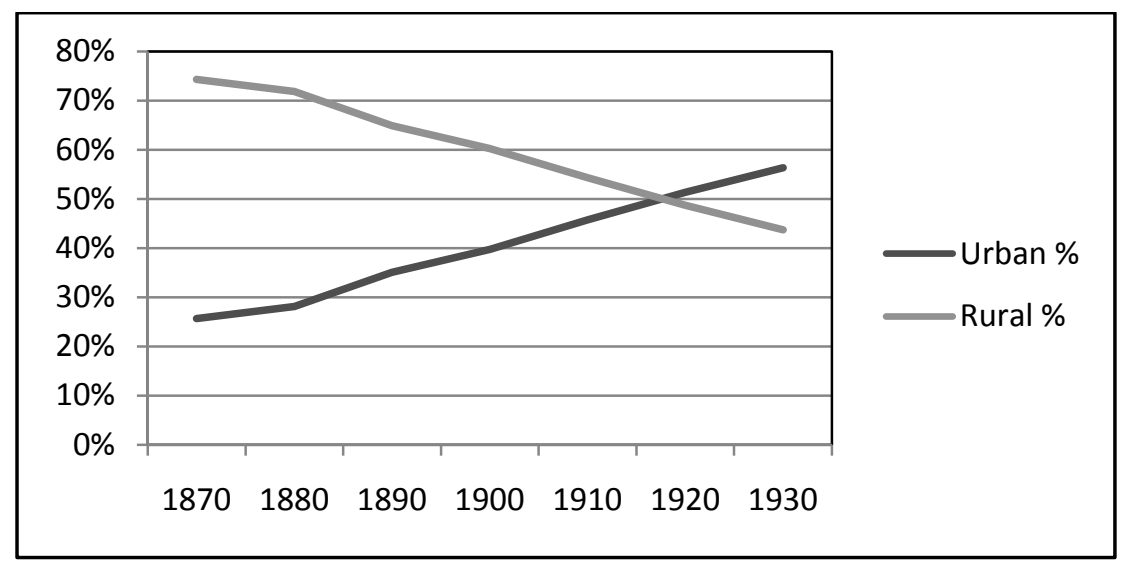

Source: Carter et al. 2006, 1:103-104

Increased segregation of work and home lives accompanied the rural-to-city migration. In rural life, home and work were typically contingent, the farmhouse on the farm, the living quarters above the shop. The separation of home and work meant that neighbors could no longer so readily witness how hard and well one worked, thereby reducing the potential of work for providing identity and status in ones community.

With the degradation of work and the decline of community, the easiest and most practical way to signal how hard one has worked is through ones consumption. As Veblen noted: “To sustain one's dignity - and to sustain one's self-respect - under the eyes of people who are not socially one's immediate neighbors, it is necessary to display the token of economic worth, which practically coincides pretty closely with economic success" (Veblen, 1919: 393). Further,

“One's neighbours, mechanically speaking, often are socially not one's neighbours, or even acquaintances; and still their transient good opinion has a high degree of utility. The only practicable means of impressing one's pecuniary 
ability on these unsympathetic observers of one's everyday life is an unremitting demonstration of ability to pay" (1899: 86-87).

As the metropolis grew and became more segregated along class, racial, and ethnic lines, the divorce between work and the rest of life became even more pronounced, especially as workplaces were segregated from residential areas. Klein and Kantor describe the process as one whereby

"The larger [cities] grew, the more insulated each of their sections became. Most people no longer lived near where they worked...Cut off from all but superficial contact with those different from themselves, they lost their sense of a larger community beyond the neighborhood" (1976: 111).

New transportation means also allowed for further segregation of home and work. ${ }^{32}$ The proliferation of streetcars allowed workers to traverse greater distances between home and work fairly rapidly and at low cost. In his classic work on the suburbanization of Boston, Warner found that as a consequence of the expansion of streetcar lines, the primarily residential suburbs of Roxbury, West Roxbury, and Dorchester saw a collective population increase of 278 percent between 1870 and 1900 (Warner 1978, 35). Early suburbs, frequently located within actual city limits on undeveloped land, grew even more rapidly after the turn of the century, especially as

\footnotetext{
${ }^{32}$ New technologies helped alter the definition of "community" for many Americans. The rapid diffusion of technologies such as the telephone and automobile allowed one to maintain contact with those whose approval was needed even while working and living in another community. Over the thirty year period from 1900-1930, the number of telephones for every 100 Americans went from 2 to 41 ; the number of cars per 100 Americans increased from 1 to 20 (Fischer and Carroll 1988, 1154). Furthermore, it has been shown that automobile adoption leads to telephone adoption, but telephone adoption does not lead to automobile adoption (Fischer and Carroll 1988). While these results are consistent with a variety of explanations, they fit nicely into a story where automobiles are used to move away.
} 
automobile ownership became more widespread. By the 1920s, the suburbs of the nation's largest cities were growing twice as fast as the cities themselves (Hawley 1956).

The link between increasing suburbanization and automobile ownership is shown by the fact that in 1930, more than half of commuters into medium-sized cities came by car (Jackson 1985, 174). During the 1920s, downtown office space in the ten largest cities tripled (Jackson 1985, 174). The average distance to work for an attorney in Manhattan increased from 2.91 miles in 1875 to 5.17 miles in 1928. In Binghampton, the distance increased from .32 miles in 1870 to 1.05 miles in 1926 (Jackson 1985: 319, 323). Clearly, the divide between work and the rest of life was growing.

Industrialization also changed communities in a gender related manner. In preindustrial work, husband and wife frequently worked as a partnership, whether on the farm, in handicraft industry, or in retail shops. Husbands and wives had similar work and social schedules, as well as some overlap in social circles (Vanek 1980:429). But when males became wage workers outside the home, wives were left caring for the home and children. The loss of control over work resulted in the segregation of work and leisure/family activites for men, but provided no such impetus for women who continued to work in the house, weakening familial bonds (Vanek 1980: 429). Tilly and Scott (1978) found that women's participation in activities perceived as "economically productive" declined as an economy industrialized (144-145). ${ }^{33}$ Because husbands

\footnotetext{
${ }^{33}$ Interrante points out that "Many, if not all, of the village-centered institutions sold goods and provided services - food, clothing, education, health care, entertainment - which farm women had produced or performed themselves, and over which farm families had retained a close and immediate control. Metropolitanism [accompanying industrialization] interrupted that relationship and thus represented a reorganization of the social relations of consumption" (1979: 158).
} 
earned and therefore more greatly controlled money, women became less empowered, more dependent.

\section{RISING INEQUALITY AND THE HEIGHTENED CHALLENGE}

\section{TO SOCIAL RESPECTABILITY}

Historically, it was through work and community that social approval, and thus social status and self-esteem, could be acquired and maintained. But, as noted above, industrialization degraded much work and reduced the percent of population living in traditional communities such that they could no longer as readily serve their traditional status-giving functions. ${ }^{34}$ Moreover, and pertinent to the Protestant ethic, how hard one worked became less directly observable. What more readily caught attention was how much one could consume, which could stand, more or less, as an indication for how hard one worked. The greater inequality that accompanied this period meant that consumers would have to stretch further to maintain their relative social standing. ${ }^{35}$

Where income and wealth inequality are greater, the amount that must be consumed to create the impression of higher status is greater. But inequality would only have this effect where a belief in the potential for vertical mobility is strong. ${ }^{36}$ In

\footnotetext{
${ }^{34}$ Porter points out that "Historically, people were not drawn away from family and community involvement for the sake of paid work until industrialization and the structured work of mass-producing factories" (2004: 433).

${ }^{35}$ Whereas in this study the focus is upon the struggle to maintain status and social respectability, Bauman views this transformation as a quest for freedom: "Consumer freedom was originally a compensation for the loss of the freedom and autonomy of the producer. Having been evicted from production and communal self-rule, the individual drive to self-assertion found its outlet in the market game.... The less freedom exists in the other spheres of social life, the stronger is the popular pressure on the further extension of consumer freedom - whatever its costs" (1888: 95). Clearly these differing perspectives are complementary.

${ }^{36}$ Beyond Veblen, Duesenberry is one of the few well-known economists to identified a relationship between belief in social mobility and consumption: “...recognition of upward mobility as a social goal converts the drive for self-esteem into a desire for high social status [which] requires the maintenance of a high consumption standard" (1949: 31).
} 
societies where relatively little potential for vertical mobility is believed to exist, individuals understand their class status as more fixed and known. They possess the status of their parents, which was that of their grandparents and so on. Should their status be low, it is not the result of a personal failing. Moreover, if an individual were to attempt to show greater status through consumption, it would more readily be viewed as negative, as "show-off" behavior. Rather than signaling virtue, it would signal a character flaw.

Also stimulating consumption is the fact that if identity is less given by inherited status (class membership, community, ethnicity, religion, and even gender), then individuals feel more responsible for their lives and self-identity. There is a greater sense of individuality, and self-identity becomes a project. Consumption acts as a signaling device for identity, a means to define ones self and to project this definition to others. Maintaining if not improving this identity is a never-ending project.

Where there is a strong belief that vertical mobility is possible, a substantial increase in inequality could be expected to prompt households to respond in one or more of three ways: People might consume more of their incomes, forcing them to save less; they might become more indebted to enable greater consumption; and they might increase the hours they work to enable them to increase their income and hence consumption levels. As the evidence presented below demonstrates, as a whole, U.S. households did two, and possibly all three, especially during the last decade of the period $1870-1930$ when inequality most dramatically increased. ${ }^{37}$

\footnotetext{
${ }^{37}$ Theoretically, it is, of course, possible that individuals with low discount rates might increase saving so as to gain higher status later by becoming richer. However, the fall in the saving rate suggests that they were a minority at most. Also, working against this possibility is the fact that higher present status is an aid
} 
Although wealth and income gaps seemed to have narrowed during both the Civil War and World War I, available evidence suggests that inequality progressively increased after the Civil War up until 1929. An explosion in this rising inequality especially characterized the 1920s (Lindert 2000: 186ff). Part of the reason for this rising inequality was the shift away from farming, an occupation that had traditionally had less inequality: in 1870 , the top 10 percent of farmers owned 59 percent of farm wealth, while the top 10 percent of nonfarmers owned 81 percent of nonfarm wealth. (Soltow 1975:108).

Rising inequality after 1870 in the U.S. fits the hypothesis set forth by Simon Kuznets in a landmark article (1955), contending that the earlier stages of economic development were characterized by rising inequality. The reason is that "Since... the intrasectoral distribution of income is necessarily wider in the urban sector than in the rural sector, a major shift in population from a sector with low inequality to one with greater inequality increases the weight of the unequal sector, thus raising overall inequality" (Moran 2005: 212). Williamson (1991) has offered support for this view.

\section{Exploding inequality in the 1920s}

The transformation of the Protestant Ethic picked up substantial momentum during the 1920s as war-time production was more fully converted to producing consumer durables $^{38}$ for which inequality fueled increased demand.

On the whole, the period leading up to the crisis of 1929 was highly prosperous. Between 1922 and 1929, GNP grew at an annual rate of 4.7 percent and unemployment averaged 3.7 percent (White 1990: 69). However, productivity gains substantially

\footnotetext{
for improving future status, thus providing a bias to a high discount rate.

${ }^{38}$ Lewis Mandell points out that "the necessities of war had produced a massive U.S. industrial base, which was prepared to produce consumer durables at a tremendous pace" (1990: xiv).
} 
outpaced wages, with important distributional consequences. As Long pointed out, "So large is labor's share of national income that any substantial disparity between productivity and real wages would exert great impact on the other shares - either largely expropriating them or presenting them with huge windfalls" (1960: 112). Accordingly, the share of total income received by the richest five percent of the population increased from 24.3 percent in 1919 to 33.5 percent in 1929 . By 1928 the richest 10 percent received 46 percent of total income. The disposable income of the top one percent of taxpayers rose 63 percent (Livingston 2009: 38). Between 1919 and 1929, the share of income taken by the top one-hundredth of one percent soared from about 1.7 to 5 percent (Saez 2009). Phillips estimates that whereas there were about 7,000 millionaires in 1921 or 1922 , by 1929 there were about 30,000 (2002: 11). The real prosperity of the 1920 s was reserved for those residing in the top of the income scale (Bernstein, 1966; Stricker 1985).

Contributing to this heightened inequality were tax reforms that reduced corporate taxes and lowered the maximum personal income tax rate from 75 to 25 percent (Smiley 1998, 218). ${ }^{39}$ Holt (1977) notes that per capita income for the lowest 93 percent of the non-farm working class actually fell by four percent from 1923 to 1929.

\section{Automobiles, Houses, Consumer Durables, and Social Status}

Rising inequality meant that households had to consume more to maintain their relative status. The advent of automobiles, single-family-dwelling houses, and new consumer durables dramatically fueled this race to keep up. Although inequality

\footnotetext{
${ }^{39}$ President Calvin Coolidge and his Treasury Secretary Andrew Mellon energetically campaigned to drastically cut taxes on the highest incomes. During the 1920s, only the very highest portion of the income distribution was subject to federal income taxes. Thus the large tax cuts undertaken in 1921, 1924, and 1926 benefited only the wealthy.
} 
increased, household incomes rose dramatically, with real GDP per capita, measured in 1990 dollars, rising from $\$ 2,445$ in 1870 to $\$ 6,899$ in 1929 (Maddison 2006).

Furniture always played a role in marking social status. However, it was generally hidden inside and thus only visible to the select few who were invited in. Freestanding houses and automobiles opened up extraordinary potential to flash status, because, as Wilkinson and Pickett point out, "research confirms that the tendency to look for goods which confer status and prestige is indeed stronger for things which are more visible to others" (2009: 225). This was especially true of the automobile, since it could accompany its owner (of course, horse-drawn coaches had, earlier, performed the same function, but they were far less convenient in urban environments). Olney makes clear the importance of the advent and spread of automobiles for household spending:

"In 1899, 65 percent of durable goods spending (and 5 percent of total consumption expenditure) was for household goods, but just 7 percent (barely .05 percent of total consumption expenditure) was for transportation goods, and even this was mostly for horse-drawn vehicles. Thirty years later, transportation goods accounted for 36 percent of total spending for durable goods (and 4.4 percent of total consumption expenditure), while household goods accounted for only 51 percent (but now over 6 percent of total consumption expenditures)" (1991: 33). The automobile industry expanded dramatically from the very beginning of the century up until 1929, with only a brief interruption during the First World War. In 1929, over four million vehicles were produced, a level not attained again until 1949. Two of every three families owned cars by 1929 (Livingston 1994: 108). 
Arguably, no single new consumer good had theretofore more transformed society than the automobile. Not only was the automobile an immediate symbol of status, it also helped fuel a housing boom by making suburban living more viable. Because suburban land was less expensive, housing could be in individual units as opposed to the multi-unit apartment buildings on more expensive in-town land. A detached house has far greater potential for revealing status than units encased within an apartment complex. Automobiles and free-standing houses were not only primary, but alsos mutually reinforcing, status symbols.

During the 1920s, as the wealthy took every larger shares of total income, they bought ever-more expensive houses, vacation properties, automobiles, country club memberships and other luxury items. Automobiles made possible the dramatic expansion of private playgrounds for the rich - so-called country clubs. The real estate boom was especially robust in vacation facilities such as hotels, tourist cottages, and motor courts (Grebler, et. al. 1956). This put intense pressure on all with lower incomes to consume more to maintain their relative social standing.

By the late 1920s, about 80 percent of U.S. households had radios, not only connecting people to a greater world, but also bringing advertising into living rooms. Radio advertising helped erode the historical thriftiness of American families. Debt-shy households were encouraged to buy on the more value-neutral term, "credit," as opposed to taking out loans. And to enable them to better do so, installment-plan financing developed. ${ }^{40}$ Between 1913 and 1929 the ratio of private credit to Gross Domestic Product nearly doubled.

\footnotetext{
${ }^{40}$ Bell characterizes the "the invention of the installment plan [as] the most 'subversive' instrument that undercut the Protestant ethic...[and] Marketing and hedonism became the motor forces of capitalism" (Bell
} 
FIGURE 4: PERCENTAGE OF GDP SPENT ON AUTOMOBILES AND

CONSUMER DURABLES, 1870-1930

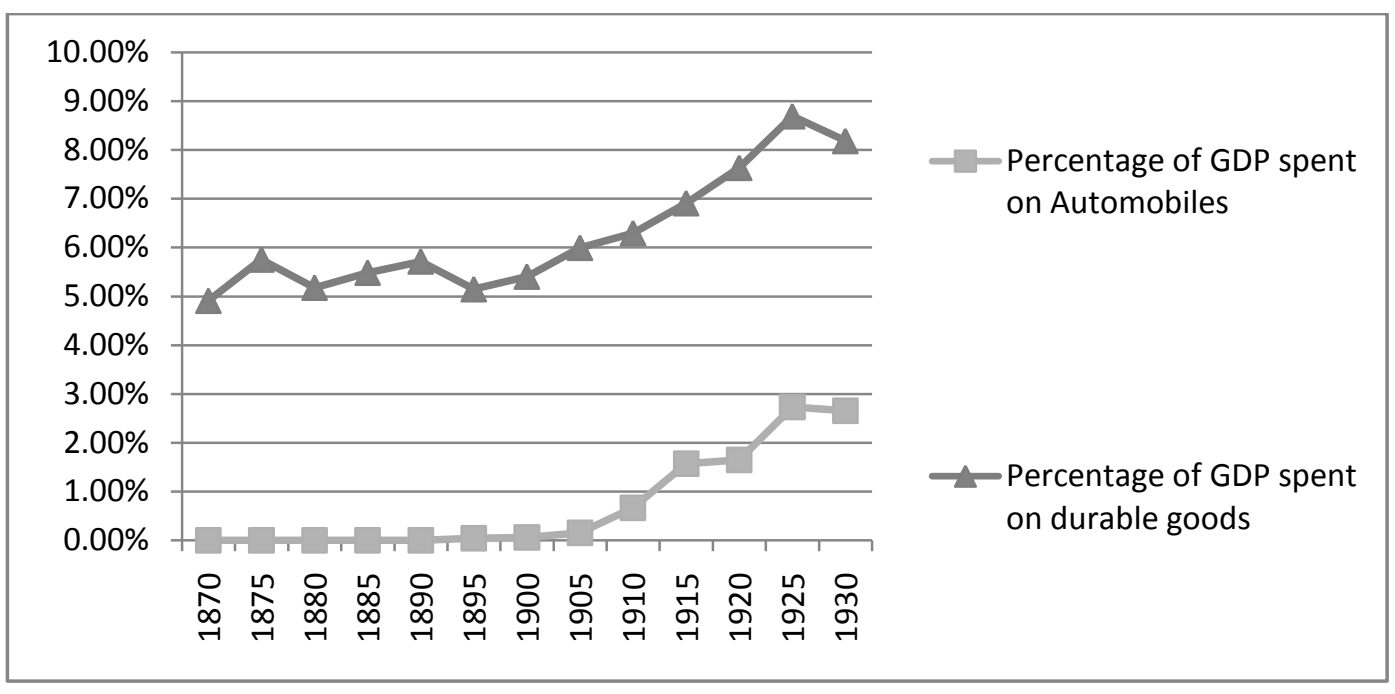

Source: Carter et al. 2006, 3:24-25; 3:270-271

FIGURE 5 : PERCENTAGE OF DURABLE GOODS SPENDING ON SELECT GOODS, 1870-1930

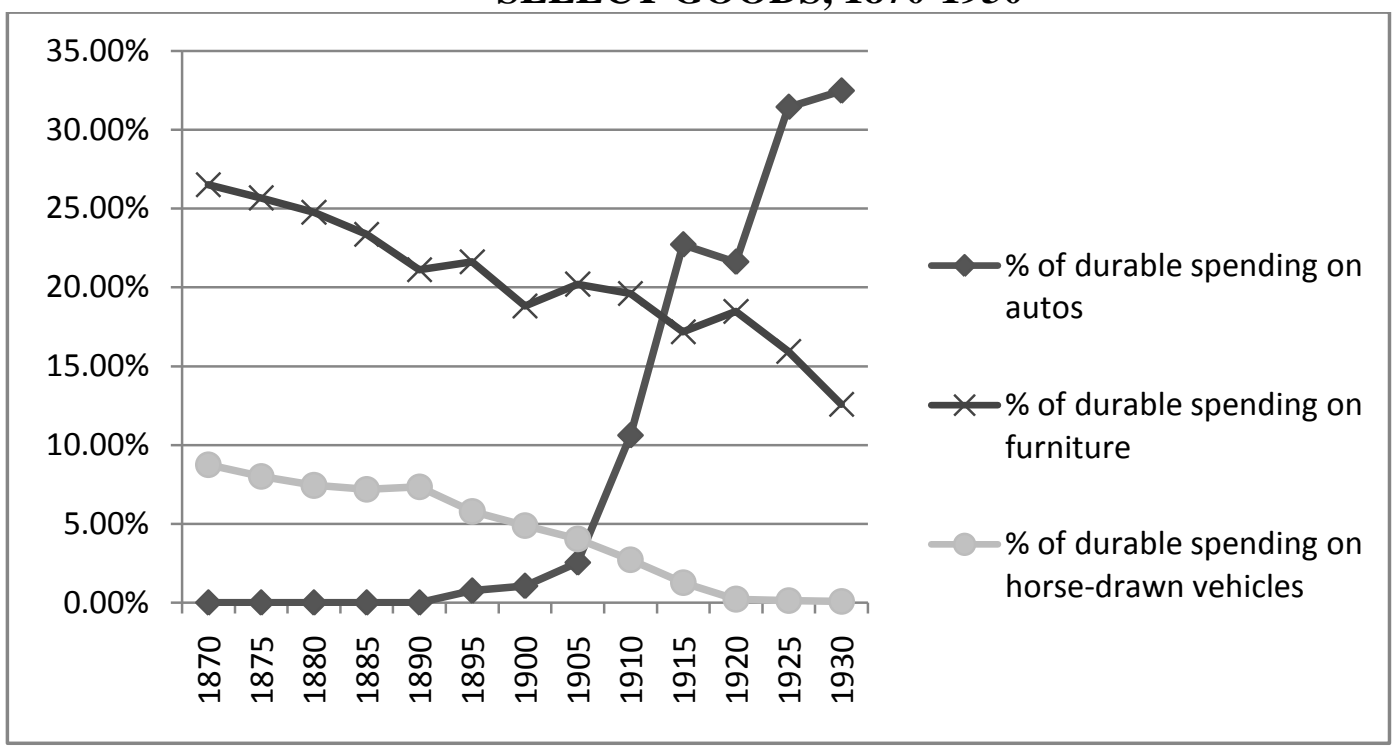

Source: Carter et al. 2006, 3:270-271.

1996: 38). 
"Shoestring mortgages" enabled property to be bought on margin. The expansion of such credit instruments unhinged the traditional relationship between income and spending (Olney 1991: 130-31), and thereby increased the potential for conspicuous consumption. This marked a significant change from the nineteenth century when "...the things that a self-respecting thrifty American family would buy on the installment plan were a piano, a sewing machine, some expensive article of furniture, and perhaps sets of books. People who made such purchases didn't talk about them. Installment buying wasn't considered quite respectable" (Ayres 1926: 13 cited in Olney 1991: 130-31).

It should be noted that not all of the pressure to consume more falls so clearly within the realm of a struggle to maintain social status. Rising inequality also created externalities that required households to increase spending for the welfare of their families, and especially their children. Robert Frank has addressed the manner in which this works in housing:

"Increased spending at the top of the income distribution has not only imposed psychological costs on families in the middle, it has also raised the cost of achieving many basic goals. Few middle-income parents, for example, would be comfortable knowing that their children were attending below-average schools. Yet the amount that any given family must spend to avoid that outcome depends strongly on the amounts that others spend.... [Moreover], people cannot send their children to a public school of even average quality if they buy a home in a school district in which house prices are well below average" (2000: 258). 
The super-rich households were ever in competition with each other for the very pinnacle of status, with the consequence that "In the consumer race the finishing line always moves faster than the fastest of runners" (Bauman 2000: 72). This put pressure on the lesser rich who also wished to be seen as at the very top. This pressure was reinforced by the advertising that kept the consumption standards of the rich and famous on public display. Business spending on advertising increased from $\$ 2.28$ billion in 1919 to $\$ 3.43$ billion in 1929 (Olney 1991: 137), keeping the consumption practices of the super wealthy ever on display. As Edsforth notes, "In the 1920s, advertising's pictorial images portrayed the comforts and luxuries of the well-to-do while advertising's words promised everyone access to these things...[and] corporate elites advertised the 'Democracy of Goods' and urged every citizen to partake of the pleasures offered by the new and exciting mass popular culture" (1998: 260; 266). In Middletown (1929), the Lynds argued that workers worked ever harder, not due to a work ethic, but because of their expanding wants, ever stimulated by advertising and films.

As inequality dramatically increased during the 1920s, the struggle by households to maintain their relative status resulted in reduced saving, ${ }^{41}$ greater indebtedness, and possibly more work hours for households. Personal saving as a percent of disposable income declined from 6.4 percent in the $1898-1916$ period to 3.8 percent in the 19221929 period (Olney 1991: 48). However, who continued saving is revealing. Whereas the top one percent of income recipients accounted for 49 percent of total saving in 1922, this

\footnotetext{
${ }^{41}$ The argument set forth here is directly opposite that of Keynes (1936: 372-75). For Keynes, an increase in inequality could be expected to increase saving since wealthier households have higher marginal propensities to save than do the less-well-off. What Keynes failed to take into account is the manner in which rising inequality pressures all households beneath the top to increase consumption to maintain their relative social status. For an extended discussion of Veblen's theory of consumer behavior applied to U.S. saving behavior, see Brown 2008; Wisman 2009.
} 
figure soared to 80 percent by 1928 (Lampman 1962: 236, Table 111). Thus, in their status-driven struggle to consume more, the lower ninety-nine percent were saving very little.

In their struggle to maintain their relative social status in the face of rising inequality, Americans became more indebted, providing further evidence of the significant decline in Protestantism's ascetic component. Debt as a percent of income increased from 4.64 percent in 1919 to 9.34 percent in 1929 (Olney 1991: 88-89). Total consumer debt, which was $\$ 3$ billion in 1920, rose to $\$ 7.2$ billion by 1929 (Bernstein 1998: 194). Calder notes that "By 1930, installment credit financed the sales of 60-75 percent of automobiles, 80-90 percent of furniture, 75 percent of washing machines, 65 percent of vacuum cleaners, $18-25$ percent of jewelry, 75 percent of radio sets, and 80 percent of phonographs" (1999: 201). Between 1921 and 1929, consumer spending on durables grew 116 percent, whereas spending on non-durables grew by 34 percent (Hall and Ferguson 1998: 19). While some of these durables represented labor-saving technology that enhanced the standard of living, a large quantity were goods that could also serve as indicators of income, and thus, status.

This rise in indebtedness fits the Veblenian hypothesis that in a society in which vertical mobility is believed to be highly fluid, increasing gaps in income all along the spectrum would stimulate everyone to struggle harder to meet their consumption status targets, as those at the very top compete among themselves for the very apex of status. ${ }^{42}$

\footnotetext{
${ }^{42}$ As Veblen put it, "in any community in which class distinctions are somewhat vague, all canons of reputability and decency, and all standards of consumption, are traced back by insensible gradations to the usages and habits of thoughts of the highest social and pecuniary class -- the wealthy leisure class" (1899: 104).
} 
A third possible response of households in their struggle to maintain their relative social standing in the face of rising inequality would be to work longer hours. Although the work week continued its contraction during the 1920s, Bernstein points out that "New expectations regarding appropriate family income levels... encouraged more women to enter the labor market" (1998: 195). This relationship is supported by a study that found "that increased inequality induces people to work longer hours [and] ...the underlying cause is the Veblen effect of the consumption of the rich on the behaviour of those less well off' (Bowles and Park 2005: F410). ${ }^{43}$

Rising inequality, especially in a social context of degraded work, weakened community, and new consumer durables, served to exaggerate the devaluation of work and the decline of community resulting from industrialization. Inequality reduces the potential for work to serve as an adequate medium for achieving fulfillment. Because of the way inequality propels households toward consumption to maintain their social standing, where there is a trade-off between work quality and income, inequality encourages workers to choose the latter. The labor market reinforces this tendency. As Lane points out, "In the labor market where workers are free to choose, there is poor information on quality of work life, the default values of money are strong, family benefits flow from money but not for intrinsic satisfaction" $(1991,406)$. Thus, work becomes more biased toward a means to the end of higher consumption and away from its potential for serving as an outlet for self-expression and creativity.

\footnotetext{
${ }^{43}$ As noted earlier, productivity increased significantly during the 1920s. Veblen, however, contended that increased productivity would lead to greater conspicuous consumption rather than fewer work hours:

"As increased efficiency makes it possible to procure the means of livelihood with less labour, the energies of the industrious members of the community are bent to the compassing of a higher result in conspicuous expenditure, rather than slackened to a more comfortable pace" (1899: 111).
} 
Inequality reduces the potential for community because, as Irvin reports, it reduces social capital: "Where there is more income inequality, poorer people are more likely to feel out of place participating in community groups, more likely to feel ill at ease and to think that they will make fools of themselves and be looked down upon" $(2007,15)$. In their survey of studies on trust, Wilkinson and Pickett find that "With greater inequality, people are less caring of one another, there is less mutuality in relationships, people have to fend for themselves and get what they can - so, inevitably, there is less trust.... High levels of trust mean that people feel secure, they have less to worry about, they see others as co-operative rather than competitive" $(2009,56 ; 57)$

In devaluing the potential for work and community to provide social certification and personal fulfillment, inequality fed a material progress vision, the view that evergreater material abundance is the key to happiness. ${ }^{44}$ This change in perception was manifest in the drastic increase in consumption during the early part of the $20^{\text {th }}$ century, particularly in those goods that more ably suggested ones income level, as individuals competed to indicate their worthiness.

\section{FINAL REFLECTIONS}

The Protestant Ethic was a defining characteristic of America's cultural and economic experience. Just as its birth in Europe toward the end of the Middle Ages was due to evolving socio-economic conditions, so too was its transformation in the U.S. between 1870 and 1930. The birth of the Protestant Ethic had generated two behavior codes that would favor capital accumulation and economic dynamism, those of ascetic behavior in consumption and the value of hard work. The transformation of this ethic,

\footnotetext{
${ }^{44}$ For an extended discussion, see Wisman 2003.
} 
whereby asceticism greatly weakened as a consequence of industrialization in the U.S., heralded the birth of a consumer-driven society.

This transformation of the Protestant Ethic has meant that social certification, social status, and self-respect have come to be sought increasingly in consumption as opposed to work and community. Hard work remained critically important, but its social recognition depended increasingly on the level of consumption it permitted. However, the resulting status-driven competitive consumption race now poses an unanticipated challenge - avoiding environmental devastation. Indeed, avoiding devastation of our habitat may be the greatest challenge ever faced by humanity (Wisman 2011).

Although social sciences are turning their analyses toward this challenge, mainstream economic science is ill-equipped for adequately participating. The fundamental reason is its steadfast refusal to examine the manner in which preferences are, at least in part, socially constructed. The pretended queen of the social sciences needs to widen its framework to be able to grasp the social dynamics that heterodox economists such as Veblen so keenly explored. An understanding of the cultural dynamics represented by the Protestant Ethic reminds us of the theoretical and social costs of this mainstream stance, and the need for an economic science capable of incorporating socio-cultural dynamics into its analytical framework.

\section{REFERENCES}

Applebaum, Herbert. 1998. The American Work Ethic and the Changing Work Force. Westport, CT: Greenwood Press.

Ayres, Milan V. 1926. Installment Selling and Its Financing: A Report by the Economic Policy Commission to the Executive Council and a Report to the Economic Policy Commission. N.p.: American Bankers Association. 
Bauman, Zygmunt. 1988. Freedom. Minneapolis: University of Minnesota Press.

Bauman, Zygmunt. 2000. Liquid Modernity. Malden, MA: Blackwell.

Bauman, Zygmunt. 2005. Work, Consumerism and the New Poor, $2^{\text {nd }}$ ed. Berkshire, England: Open University Press.

Bell, Daniel. 1976. The Cultural Contradictions of Capitalism. New York: Basic Books.

Bell, Daniel. 1996. “The Protestant Ethic,” World Policy Journal, 13 (3), Fall: 35-39.

JSTOR. Accessed July 14, 2010.

Bernstein, Irving. The Lean Years: A History of the American Worker, 1920-33. Boston: Penguin Books, 1966.

Bernstein, Michael A. 1998. "The American Economy of the Interwar Era," in Calvin Coolidge and the Coolidge Era, John Earl Haynes, ed. Washington, D.C. Library of Congress: 191-213.

Braverman, Harry. 1974. Labor and Monopoly Capital: The Degradation of Work in the Twentieth Century. New York: Monthly Review Press.

Bright, James R. 1958. Automation and Management. Norwood, MA: The Plimpton Press.

Brown, Christopher. 2008. Inequality, Consumer Credit and the Saving Puzzle. Northampton, Mass.: Edward Elgar.

Buchholz, Rogene A. 1998. "The Ethics of Consumption Activities: A Future Paradigm?” Journal of Business Ethics, 17 (8):871-882. JSTOR. Accessed July 14, 2010.

Calder, Lendol. 1999. Financing the American Dream: A cultural History of Consumer Credit. Princeton, N.J.: Princeton University Press.

Carnegie, Andrew. 2006. The "Gospel of Wealth" Essays and Other Writings. David Nasaw, ed. New York: Penguin.

Carter, Susan B. et al. ed. 2006. Historical Statistics of the United States: Earliest Times to the Present - Millennial Edition. 5 vols. New York: Cambridge University Press.

Collins, Jane. 2002. "Deterritorialization and Workplace Culture," American Ethnologist, 29 (1): 151-71. JSTOR. Accessed September 9, 2011.

Conwell, Russell. 1915. Acres of Diamonds. New York: Harper \& Brothers.

Davis, Arthur K. 1944. Veblen on the Decline of the Protestant Ethic, Social Forces, 22 
(3), March: 282-86. JSTOR. Accessed January 13, 2010.

DeLong, J. Bradford. 1997. "Slouching Towards Utopia?: The Economic History of the Twentieth Century - XIII. The Roaring Twenties-“ http://www.j-bradforddelong.net/TCEH/Slouch_roaring13.html. Accessed January 16, 2010.

de Tocqueville, Alexis. 1945. Democracy in America. Henry Reeve, trans. Vols. 1 and 2. New York: Vintage.

Duesenberry, James S. 1949. Income, Saving, and the Theory of Consumer Behavior. Cambridge, MA: Harvard University Press.

Edsforth, Ronald. 1998. "Made in the U.S.A.: Mass Culture and the Americanization of Working-Class Ethnics in the Coolidge Era," in Calvin Coolidge and the Coolidge Era, John Earl Haynes, ed. Washington, D.C. Library of Congress: 244-72.

Eisenberger, Robert. 1989. Blue Monday: The Loss of the Work Ethic in America. New York: Paragon House.

Fischer, Claude S. and Glenn R. Carroll. 1988. "Telephone and Automobile Diffusion in the United States, 1902-1937." American Journal of Sociology, 93 (5): 1153-1178.

JSTOR. Accessed September 1, 2011.

Frank, Robert H. 2005. "Positional Externalities Cause Large and Preventable Welfare Losses," American Economic Review, 95 (2): 137-41. JSTOR. Accessed July 24, 2011.

Furnham, A. 1984. "The protestant work ethic: A review of the psychological literature," European Journal of Social Psychology, 14: 87-104. EBSCO Academic Search Premier. Accessed January 13, 2010.

Furnham, Adrian. 1990. The Protestant Work Ethic: The Psychology of Work-Related Beliefs and Behaviors. London: Routledge.

Gilligan, Carol. "Concepts of Self and Morality." 2000. The Presence of Others. 3rd ed. Ed. Andrea Lunsford and John J. Ruszkiewicz. New York: St. Martin's: 169-178.

Graeber, David. 2011. "To Have is to Own"

http://www.canopycanopycanopy.com/10/to_have_is_to_owe (Accessed 9-8-11).

Granovetter, Mark. 1984. "Small is Bountiful: Labor Markets and Establishment Size." American Sociological Review, 49 (3): 323-334. JSTOR. Accessed June 28, 2011.

Grebler, Leo, David M. Blank and Louis Winick. 1956. Capital Formation in Residential Real Estate: Trends and Prospects. Princeton: NBER and Princeton University Press. 
Gutman, Gerbert G. 1973, "Work, Culture, and Society in Industrializing America, 18151919," American Historical Review, 78 (3), June: 531-88. JSTOR. Accessed July 14, 2011.

Hall, Thomas E. and J. David Ferguson. 1998. The Great Depression: An International Disaster of Perverse Economic Policies. Ann Arbor: University of Michigan Press.

Hatton, Timothy J. and Jeffrey G. Williamson. 1991. "Wage Gaps between Farm and City: Michigan in the 1890s." Explorations in Economic History, 28 (4): 381-408.

ScienceDirect. Accessed August 16, 2011.

Hawley, 1956. "The Changing Shape of Metropolitan America.” Glencoe, IL: Free Press.

Holt, Charles F. 1977. "Who Benefited from the Prosperity of the Twenties?" Explorations in Economic History, 14 (3): 277-89. Periodicals Archive Online. Accessed July 12, 2011.

Interrante, Joseph. 1979. "You Can't Go to Town in a Bathtub: Automobile Movement and the Reorganization of Rural American Space, 1900-1930," Radical History Review, 21, Fall: 151-68. E-Duke Journals Scholarly Collection. Accessed January 16, 2010.

Irvin, George. 2007. "Growing Inequality in the Neo-liberal Heartland," Post-Autistic Economics Review, 43: 1-23. PAE Review. Accessed September 5, 2010.

Jackson, Kenneth T. 1985. Crabgrass Frontier: The Suburbanization of the United States. New York: Oxford University Press.

Keynes, John Maynard . 1930. Essays in Persuasion.” New York: Harcourt, Brace and Co.

Keynes, John Maynard. 1936. The General Theory of Employment, Interest, and Money. New York: Harcourt, Brace \& World, 1965.

Klein, Maury and Harvey A. Kantor. 1976. Prisoners of Progress: American Industrial Cities 1850-1920. New York: Macmillan Publishing Co.

Kuznets, Simon. 1955. "Economic Growth and Income Inequality," American Economic Review, 45 (1): 1-28. JSTOR. Accessed January 8, 2010.

Lacey, Robert. 1986. Ford: The Men and the Machine. Boston: Little, Brown \& Co.

Lampman, Robert. 1962. The Share of Top Wealth-Holders in National Wealth 19221956. A Study by the National Bureau of Economic Research. Princeton, N.J., Princeton University Press. 
Landes, David. 1998. The Wealth and Poverty of Nations. New York: W.W. Norton.

Lane, Robert E. The Market Experience. New York: Cambridge University Press, 1991.

Lindert, Peter H. 2000. "Three Centuries of Inequality in Britain and America,"

Handbook of Income Distribution, Vol. 1, edited by A.B. Atkinson and F. Bourguignon.

Amsterdam: Elsevier Science B.V.

Livingston, James. 1994. Pragmatism and the Political Economy of Cultural

Revolution, 1850-1940. Chapel Hill: University of North Carolina Press.

Livingston, James. 2009. "Their Great Depression and Ours," Challenge, 52 (3),

May/June: 34-51. EBSCO Business Source Premier. Accessed July 9, 2011.

Long, Clarence D. 1960. Wages and Earnings in the United States, 1860-1890.

Princeton: Princeton University Press.

Lutz, Tom. 1996. "'Sweat or Die': The Hedonization of the Work Ethic in the 1920s ,"

American Literary History, 8 (2), Summer: 259-83. JSTOR. Accessed July 15, 2011.

Lynd, Robert S., and Hellen Merrel Lynd. 1929. Middletown: A Study in Conteemporary Aemrican Culture. New York: Harcourt.

Maddison, Angus. 2006. The World Economy. OECD iLibrary. Accessed October 27, 2011.Mandell, Lewis. 1990. The Credit Card Industry: A History. Boston: Twayne.

Mayhew, Anne. 1972. "A Reappraisal of the Causes of Farm Protest in the United States, 1870-1900." The Journal of Economic History. 32.2 (1972): 464-475. JSTOR. Accessed August 17, 2011.

Montgomery, David. Workers' Control in America. Cambridge: Cambridge University Press, 1987.

Montgomery, David 1983. "Workers' Control of Machine Production in the Nineteenth Century," The Labor History Reader, ed. Daniel J. Leab. Urbana: University of Illinois Press.

Moran, Timothy Patrick. 2005. "Kuznets's Inverted U-Curve Hypothesis: The Rise, Demise, and Continued Relevance of a Socioeconomic Law," Sociological Forum, 20 (2), June: 209-44. EBSCO Academic Search Premier. Accessed August 10, 2010.

Olney, Martha L. 1991. Buy Now, Pay Later. Chapel Hill: University of North Carolina.

Phillips, Kevin (interview). 2002. "Too Much Wealth, Too Little Democracy," Challenge, 45(5): 6-20. EBSCO Business Source Premier. Accessed July 23, 2011. 
Polanyi, Karl. 1944. The Great Transformation. Boston: Beacon Press, 1957.

Porter, Gayle. 2004. "Work, Work Ethic, Work Excess," Journal of Organizational Change Management, 17 (5): 424-39. ProQuest. Accessed June 9, 2011.

Powers, Charles W. 1976. "Growth as an American Value: An Ethicist's Point of View." Growth In America. Chester L Cooper, ed. Westport, CT: Greenwood Press. 26-38.

Rawls, John. 1971. A Theory of Justice. Cambridge: Harvard University Press.

Rae, John. 1895. Life of Adam Smith. London, Macmillan and Co.

Riesman, David. 1953. The Lonely Crowd. New Haven: Yale University Press.

Rodgers, Daniel T. 1978. The Work Ethic in Industrial America, 1850-1920. Chicago:

The University of Chicago Press.

Saez, Emmanuel. 2009. "Striking It Richer: The Evolution of Top Incomes in the United States." (Update with 2007 estimates), http://elsa.berkeley.edu/ saez/saezUStopincomes-2007.pdf. Accessed July 22, 2011.

Saint-Etienne, Christian. 1984. The Great Depression, 1929-1938: Lessons for the 1980s, Stanford, CA: Hoover Institution Press.

Sayer, Andrew. 2005. The Moral Significance of Class. Cambridge: Cambridge University Press.

Scranton, Philip. 1994. "Manufacturing Diversity: Production Systems, Markets, and an American Consumer Society," Technology and Culture, 35 (3), July: 476-505. JSTOR. Accessed July 23, 2011.

Scase, Richard. 1992. Class. Minneapolis: University of Minnesota Press.

Sedgwick, Eve Kosofsky, and Adam Frank. 1995. "Shame in the Cybernetic Fold: Reading Silvan Tomkins." In Eve Kosofsky Sedgwick and Adam Frank, eds., Shame and Its Sisters: A Silvan Tomkins Reader. Durham: Duke UP: 496-527.

Shipman, Alan. 2004. "Lauding the Leisure Class: Symbolic Content and Conspicuous Consumption," Review of Social Economy, 62 (3): 277-89. Business Source Premier. Accessed August 9, 2010.

Smiley, Gene. 1998. "New Estimates of Income Shares During the 1920s." In Calvin Coolidge and the Coolidge Era: Essays on the History of the 1920. Ed. John Earl Haynes, 215-232. Washington, DC: Library of Congress.

Smith, Adam (1759), The Theory of Moral Sentiments. Indianapolis, Liberty Classics. 
Smith, Adam. 1776. An Inquiry into the Nature and Causes of the Wealth of Nations. Vol. 1 and II. Oxford: Oxford University Press, 1976.

Sohn-Rethel, Alfred. 1978. Intellectual and Manual Labour. Atlantic Highlands, New Jersey: Humanities Press.

Soltow, Lee. 1975. Men and Wealth in the United States 1850-1870. New Haven: Yale University Press.

Stricker, Frank. 1983. "Affluence for Whom? Another Look at Prosperity and the Working Classes in the 1920s," The Labor History Reader, ed. Daniel J. Leab. Urbana: University of Illinois Press.

Stricker, Frank. 1983-84. "Causes of the Great Depression, or What Reagan Doesn't Know About the 1920s," Economic Forum, 14, winter: 41-58.

Sward, Keith. 1948. The Legend of Henry Ford. New York: Rinehart \& Co.

Taylor, Frederick W. 1907. "On the Art of Cutting Metals: Presidential Address," Transactions of the American Society of Mechanical Engineers, 28 (119): 31-60. Oregon State Scholar's Archive. Accessed September 30, 2011.

Taylor, Frederick W. 1912. Shop Management. New York: Harper \& Brothers.

Tilly, Louise A. and Joan W. Scott. 1978. Women, Work, And Family. New York: Holt, Rinehart and Winston.

Tyree, Andrea and Moshe Semyonov and Robert W. Hodge. 1979. "Gaps and Glissandos: Inequality, Economic Development, and Social Mobility in 24 Countries," American Sociological Review, 44 (3): 410-24. JSTOR. Accessed July 15, 2011.

United States Senate Committee on Education and Labor. 1885. Report of the Committee of the Senate Upon the Relations Between Labor and Capital and Testimony Taken by the Committee. New York: Arno Press, 1976.

Vanek, Joann. 1980. "Work, Leisure and Family Roles: Farm Households in the United States, 1920-1955." Journal of Family History 5 (4): 422-431. Periodicals Archive Online. Accessed August 5, 2011.

Veblen, Thorstein. 1899. The Theory of the Leisure Class. New York: The Modern Library, 1934.

Warner, Sam Bass Jr. 1978. Streetcar Suburbs: The Process of Growth in Boston, 1870 1900. $2^{\text {nd }}$ ed. Cambridge, MA: Harvard University Press. 
Weber, Max. 1904. The Protestant Ethic and the Spirit of Capitalism. New York: Charles Scribners' Sons, 1958.

Whyte, William. 1956. The Organization Man. Philadelphia: The University of Pennsylvania Press, 2002.

Wiley, Hugh. "Sweat or Die.” The Saturday Evening Post. 10 April 1920. 31+. Print.

Wilkinson, Richard, and Kate Pickett. 2009. The Spirit Level: Why More Equal Societies Almost Always Do Better. London: Allen Lane.

Williamson, Jeffrey G. and Peter H. Lindert. 1980. "Long-Term Trends in American Wealth Inequality," NBER Chapters, in: Modeling the Distribution and Intergenerational Transmission of Wealth, National Bureau of Economic Research, Inc: 9-94.

Wisman, Jon D. 2003. "The Scope and Promising Future of Social Economics," Review of Social Economy, LXI (4): 1-21. Business Source Premier. Accessed August 9, 2010.

Wisman, Jon D. 2009. "Household Saving, Class Identity, and Conspicuous Consumption," Journal of Economic Issues, 43 (1), March: 89-114. MetaPress. Accessed January 20, 2010.

Wisman, Jon D. 2011. "Inequality, Social Respectability, Political Power, and Environmental Devastation,” Journal of Economic Issues, 45 (4), December: 877-900.

Zuboff, Shoshana. 1983. "The Work Ethic and Work Organization," in The Work EthicA Critical Analysis, Barbash et al., eds. Bloomington, IL: Pantagraph Printing. 153-181. 